CommentaRy on COVID-19 AND the Food System

\title{
Cultivating community resilience: How North Carolina's food council is facilitating an effective response during COVID-19
}

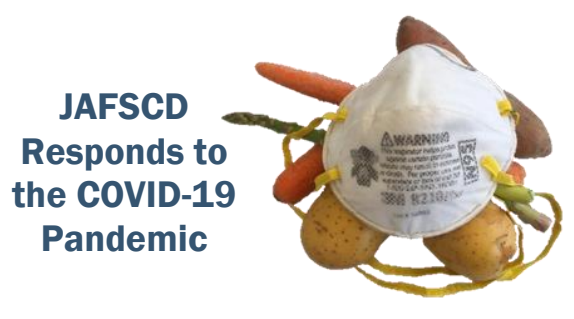

Angel Elisa Cruz ${ }^{\text {a }}$

North Carolina Local Food Council

Alice S. Ammerman ${ }^{b}$

University of North Carolina at Chapel Hill

Nancy G. Creamer ${ }^{c}$

Center for Environmental Farming Systems and North Carolina State University

Barry Nash d

North Carolina Sea Grant
Ethan J. Phillips e

University of North Carolina at Chapel Hill

Martha M. Przysucha ${ }^{\mathrm{f}}$

Carteret County Food and Health Council

Amanda S. Hege $\mathrm{g}$

Appalachian State University and Second Harvest Food Bank of Northwest North Carolina

Submitted October 14, 2020 / Published online February 22, 2021

Citation: Cruz, A. E., Ammerman, A. S., Creamer, N. G., Nash, B., Phillips, E. J., Przysucha, M. M., \&

Hege, A. S. (2021). Cultivating community resilience: How North Carolina's food council is facilitating an effective response during COVID-19. Journal of Agriculture, Food Systems, and Community Development,

10(2), 291-295. https://doi.org/10.5304/jafscd.2021.102.010

Copyright (C) 2021 by the Authors. Published by the Lyson Center for Civic Agriculture and Food Systems. Open access under CC-BY license.

\footnotetext{
Abstract

Since the onset of the COVID-19 pandemic, the North Carolina Local Food Council has strengthened its role as a cohesive and effective organization during a public-health crisis to share challenges, devise solutions, and build resilience across local food systems in North Carolina. The Council includes repre-

a* Corresponding author: Angel Elisa Cruz, Coordinator, North Carolina Local Food Council; NCSU 2721, Founders Drive, Campus Box 2609; North Carolina State University; Raleigh, NC 27695 USA; +1-919-513-0954; aecruz@ncsu.edu

b Alice S. Ammerman, Director, Center for Health Promotion and Disease Prevention, and Professor, Department of Nutrition, Gillings School of Global Public Health, University of North Carolina at Chapel Hill; alice ammerman@unc.edu

${ }^{c}$ Nancy G. Creamer, Director, Center for Environmental Farming Systems, and Distinguished Professor of Sustainable Agriculture and Community Based Food Systems, North Carolina State University; ncreamer@ncsu.edu

d Barry Nash, Seafood Technology \& Marketing Specialist, North Carolina Sea Grant; barry nash@ncsu.edu

${ }^{\mathrm{e}}$ Ethan J. Phillips, Research Intern, Center for Health Promotion and Disease Prevention, and Undergraduate Student, University of North Carolina at Chapel Hill; ethanp5@live.unc.edu

${ }^{\mathrm{f}}$ Martha M. Przysucha, Chair, Carteret County Food and Health Council; CFHC.martha@gmail.com

g Amanda S. Hege, MPH, RDN, Adjunct Faculty, Nutrition and Health Care Management, Appalachian State University, and Nutrition Educator, Second Harvest Food Bank of Northwest North Carolina; ahege@secondharvest.org
} 
sentatives from 21 organizations working across the state, as well as three representatives from regional local food councils. The Council's response to the pandemic addressed three key areas of action: (1) Coordinate responses across multiple sectors; (2) Enhance collaboration across the food supply chain; and (3) Facilitate data collection and public messaging. This paper describes the positive impacts the Council has had across North Carolina on consumers and producers of local food as a result of this collaborative network and long-established relationships across the state. Now, more than ever, the relationships and collaborative efforts of statewide organizations and partners are needed. The Council's crisis response has been strong because of the long-standing relationships of its members and its ability to share resources quickly, allowing it to work toward coordinated responses. The work of the North Carolina Local Food Council can serve as a model for other states that have state-level local food councils or want to develop them. In addition, the Council's work demonstrates how collaborations among statewide partners can foster resilience within local food systems, particularly during a public health crisis.

\section{Keywords}

COVID-19, Pandemic, Food Council, Food Policy Council, Food System, Local Food

\section{Introduction and how the state food Council responded to COVID-19}

The COVID-19 pandemic and resulting lockdowns disrupted food supply chains and endangered people's access to healthy foods, demonstrating the fragility of the food system generally. In North Carolina, a statewide stay-at-home order went into effect on March 30, 2020, and lasted until May 22, 2020 (NC Executive Order 121, 2020). As part of the stay-at-home order, many facilities were shut down, including offices, restaurants, bars, salons, gyms, day care centers, and even parks. While the limitation of movement and the closure of institutions and restaurants helped to mitigate the spread of COVID-19 in North Carolina, they also meant changing the way people access and consume food, disrupting food systems (Anderson, 2020; Havice, Marschke, \& Vandergeest, 2020; Hendrickson, 2020). In addition, the pandemic exposed other fissures in the food system and exacerbated vulnerabilities that already existed (The Rockefeller Foundation, 2020), but were less visible to the general population. Since the beginning of March 2020, the North Carolina Local Food Council' (referred to as "Council") emerged as a strong voice in addressing pandemic-related food-system challenges statewide. Together, Council members make up a cohesive and effective network that shares challenges, creates solutions, and builds resilience across local food systems.

The Council currently represents 21 statewide agencies and organizations that address food systems, along with three local-food council regional representatives. The multisector, multi-agency North Carolina Local Food Council was first enacted through legislation in 2009, but was sunsetted in 2013 by a new legislature. Many of the Council members valued the statewide collaboration and decided to continue the Council without the legislative mandate. The members spent a significant amount of time rethinking the Council's purpose, and through many open and honest conversations, the various state agencies and organizations understood the constraints and opportunities that came from working together. While the Council's focus in early 2020 was on supporting local food councils with research, education, and training, the urgent challenges of COVID-19 faced by consumers and producers from disrupted supply chains took precedence.

At the onset of the pandemic, the Council agreed to meet weekly to discuss "pinch points" in the local food system and devise potential next steps for addressing the immediate challenges. Members of

\footnotetext{
${ }^{1}$ http://www.nclocalfoodcouncil.org/
} 
the Council represent diverse food-system stakeholders across North Carolina (NC), offering an established communication stream with county and regional local food councils. Due to strong working relationships and the trust built over time, the Council had already developed productive collaborations that led to timely solutions benefitting both producers and consumers of local food.

Our response to the pandemic emerged within three key areas of action: (1) Coordinate responses across multiple sectors; (2) Enhance collaboration across the food supply chain; and (3) Facilitate data collection and messaging. Examples of how the Council contributed within each impact area are shown in Figure 1 and described in the following sections.

\section{(1) Coordinate the response across multiple sectors}

An immediate need surfacing during the stay-at-home order was to better coordinate efforts across multiple sectors. We supported this through dialogue with local food councils and the formation of response teams. One team worked with nonprofit organizations supporting farmworkers. Another supported North Carolina fisheries, and communicated challenges directly to the governor's emergency task forces.

\section{Example of Success: E-commerce and Student Internships}

Surveys of farmers in North and South Carolina (Carolina Farm Stewardship Association [CFSA], 2020; Hoffman et al., 2020) showed that local food producers needed innovative direct-marketing strategies to remain viable. To coordinate efforts between producers and consumers, the Council supported a state agency that provided technology assistance to producers to help them feature their products in an online marketplace. ${ }^{2}$ A student internship ${ }^{3}$ was established to pair students with local food producers to assist them with the construction of e-commerce websites as well as social-media outlets. These internships, funded by the Council and member organizations, not only will respond to urgent producer needs, but

\section{Figure 1. Key Areas of Action for the North Carolina Local Food Council's Response During the COVID-19 Pandemic}

\begin{tabular}{|c|c|c|}
\hline $\begin{array}{l}\text { COORDINATE THE } \\
\text { RESPONSE ACROSS } \\
\text { MULTIPLE SECTORS }\end{array}$ & $\begin{array}{c}\text { ENHANCE COLLABORATION } \\
\text { ACROSS THE FOOD SUPPLY } \\
\text { CHAIN }\end{array}$ & $\begin{array}{l}\text { FACILITATE DATA } \\
\text { COLLECTION AND } \\
\text { MESSAGING }\end{array}$ \\
\hline $\begin{array}{l}\text { Developed teams across local food } \\
\text { councils to work directly with } \\
\text { farmworkers, fisheries, cold } \\
\text { storage, and food recovery efforts } \\
\text { - Secured the placement of } 2 \text { food } \\
\text { council members to contribute to } \\
\text { the state Food Supply Chain } \\
\text { Emergency Task Force } \\
\text { - Conveyed multi-sector challenges } \\
\text { to the Governor's task force }\end{array}$ & $\begin{array}{l}\text { - Connected migrant farmworker } \\
\text { organizations with support for } \\
\text { culturally appropriate food and } \\
\text { PPE for farmworkers } \\
\text { - Connected unused refrigerated } \\
\text { trucks for food banks and food } \\
\text { hubs across the state } \\
\text { - Facilitated receipt of a USDA CFAP } \\
\text { Food Box contract award } \\
\text { - Increased support for emergency } \\
\text { food distribution for marginalized } \\
\text { communities }\end{array}$ & $\begin{array}{l}\text { - Collected experiences and evidence } \\
\text { to support farmers markets and } \\
\text { seafood retailers to stay open } \\
\text { - Shared messaging around critical } \\
\text { needs for emergency food providers } \\
\text { - Contributed a guest newspaper } \\
\text { column about the resiliency of local } \\
\text { food systems } \\
\text { - Administered surveys to understand } \\
\text { food waste, quantify the demand for } \\
\text { NC seafood, and cultural } \\
\text { preferences for emergency food }\end{array}$ \\
\hline
\end{tabular}

${ }^{2}$ The VisitNC Farms app (https://visitncfarmstoday.com/) uses cell phone technology to help residents and visitors locate nearby food producers and restaurants who provide fresh produce and seafood.

3 http://www.nclocalfoodcouncil.org/rise-for-local-foods/ 
also will provide professional-development opportunities for college students whose internships were cancelled as a result of the pandemic (Aucejo, French, Araya, \& Zafar, 2020)

\section{(2) Enhance collaboration across the food supply chain}

As restaurants were closing, more perishable products from farms were diverted to the emergency food system and local food hubs, requiring more cold storage. The Council facilitated infrastructure support by securing unused refrigerated trucks for use by food banks, food pantries, and food hubs across the state. A team affiliated with the Council also successfully applied for a USDA Coronavirus Food Assistance Program Food Box contract award, which provided a market for local farmers and increased supply in the emergency food system.

\section{Example of Success: Fisheries}

Prior to the pandemic, nearly $75 \%$ of the seafood consumed in the United States was sold in restaurants. As these and other foodservice establishments began shutting down in March 2020, the demand for seafood decreased precipitously (Cobe, 2020).

The Council responded by facilitating a commercial relationship between a seafood processor and an inland community supported agriculture distributor in the Raleigh-Durham-Chapel Hill metropolitan region that serves customers across North Carolina. The Council and its partners developed educational brochures to help customers understand the seasonality and quality of North Carolina seafood. The brochures also featured recipes to help customers prepare seafood meals at home from the species most commonly caught in $\mathrm{NC}$ waters.

\section{(3) Facilitate data collection and messaging}

Shared public messaging was identified as a critical need to support farmers markets and seafood retailers. The Council facilitated data collection and offered shared messaging. For example, a guest newspaper column written by Council members explored the resiliency of local foods and how the smaller, local supply chains demonstrated flexibility with their ability to quickly adapt and meet the changing needs of communities.

\section{Example of Success: Food Recovery after COVID-19}

Local food councils across the state identified food waste and related food insecurity issues as an important focus area for the Council. Of particular concern is conflicting information at the county level regarding guidelines for the donation of unserved prepared foods. While this was a concern before the pandemic, it has been exacerbated by COVID-19 given the rapid increase in food insecurity $(60 \%$ increase in need) and general disruption of the food chain.

With the help of a student intern recruited by one of its members, the Council conducted a survey prior to the pandemic to understand challenges around donating unserved prepared food. Given the impact of COVID-19, the Council repeated this survey after the onset of the pandemic. Armed with these data, a subcommittee of the Council set up a meeting with the North Carolina Department of Health and Human Services (DHHS) to present the survey findings and developed an agreement to collaborate with DHHS on the writing and dissemination of a more standardized, easily accessible, and comprehensive set of guidelines for prepared food recovery.

\section{Conclusion}

The pandemic changed the way food is grown, distributed, accessed, prepared, eaten, and disposed of across the state. Now, more than ever, the relationships and collaborative efforts of the Council are 
needed. The work of the Council has had positive results across the state and would not have happened had a collaborative network across organizations, agencies, and groups not been in existence before COVID-19. The Council's crisis response is stronger because of the long-standing relationships of its members and its ability to share resources toward coordinated responses.

These efforts can serve as a model for other states in which collaborations among statewide partners can foster resilience within local food systems, particularly during a public health crisis. During this pandemic, the Council fulfilled the immediate needs of those disproportionately affected by closures. Even after the pandemic, the Council will continue to identify problems and test solutions that build a more vibrant local food structure across North Carolina.

\section{References}

Anderson, M. D. (2020). Pandemic shows deep vulnerabilities. Agriculture and Human Values, 37, 559-560 https://doi.org/10.1007/s10460-020-10108-7

Aucejo, E. M., French, J., Araya, M. P. U., \& Zafar, B. (2020). The impact of COVID-19 on student experiences and expectations: Evidence from a survey. Journal of Public Economics, 191, 104271. https://doi.org/10.1016/i.jpubeco.2020.104271

Carolina Farm Stewardship Association [CFSA]. (2020). From 'scrambling' to 'devastated': The impact of COVID-19 on farms in North and South Carolina. Retrieved from https://www.carolinafarmstewards.org/wp-content/uploads/2020/06/CFSA-COVID-19-Survey-Report Final.pdf

Cobe, P. (2020, June 24). Seafood prices reflect complex supply chain. Restaurant News Online. Retrieved from https://www.restaurantbusinessonline.com/operations/seafood-prices-reflect-complex-supply-chain

Havice, E., Marschke, M., \& Vandergeest, P. (2020). Industrial seafood systems in the immobilizing COVID-19 moment. Agriculture and Human Values, 37, 655-656. https://doi.org/10.1007/s10460-020-10117-6

Hendrickson, M. K. (2020). Covid lays bare the brittleness of a concentrated and consolidated food system. Agriculture and Human Values, 37, 579-580. https://doi.org/10.1007/s10460-020-10092-y

Hoffmann, M., Davis, J., Fernandez, G., Gunter, C., Parker, M., Fair, B., Volk, E., Dankbar, H., \& Cruz, A. (2020). How did COVID-19 impact NC agriculture in April 2020? A first summary. Retrieved from https://strawberries.ces.ncsu.edu/wp-content/uploads/2020/06/COVID19-Grower-Survey-Summary V2.pdf

NC Executive Order 121. (2020, March 27). https://governor.nc.gov/documents/executive-order-no-121

The Rockefeller Foundation. (2020, July 28). Reset the table: Meeting the moment to transform the U.S. food system. Retrieved from https://www.rockefellerfoundation.org/wp-content/uploads/2020/07/RF-FoodPolicyPaper_Final2.pdf 